\title{
The Effect of Work Experience, Motivation, and Culture on Auditor Performance Mediated by Self Efficacy
}

\author{
Asri Usman ${ }^{1}$, Andi Kusumawati ${ }^{2}$, Arifuddin Mannan $^{3}$ \\ \{asriusman@unhas.ac.id ${ }^{1}$, andiuma88@gmail.com ${ }^{2}$, arifuddin.mannan@gmail.com ${ }^{3}$ \} \\ Faculty of Economics and Business, Hasanuddin University, Makassar, Indonesia.
}

\begin{abstract}
This study aims to examine the effect of work experience, motivation, and culture on auditor performance by mediating self efficacy. This study uses a quantitative approach. This research was conducted at the Inspectorate of Maros Regency and the Inspectorate of Makassar City. Data obtained using the survey instrument method used in the form of a questionnaire. The research sample of 60 respondents who in the sample using a purposive sampling method. Data were analyzed using multiple regression methods. The results showed that (1) work experience influenced auditor performance; (2) motivation affects the auditor's performance; (3) culture influences auditor performance; and (4) work experience, motivation, and culture influence the auditor's performance which is mediated by self efficacy.
\end{abstract}

Keywords:

work experience, motivation, culture, self efficacy, and auditor performance

Article Received: 18 October 2020, Revised: 3 November 2020, Accepted: 24 December 2020

\section{Introduction}

The Government Internal Supervisory Apparatus or Internal Auditor is an apparatus that conducts Internal Supervision covering the entire process of audit, review, evaluation, monitoring, and other supervision activities in the form of assistance, outreach and consultancy on the implementation of tasks and functions of the organization in order to provide adequate assurance that the activities has been carried out in accordance with the benchmarks that have been set effectively and efficiently for the interests of the leadership in realizing good governance.

In the audit standard where audit quality is influenced by expertise which states that the auditor must have the knowledge, skills and other competencies needed to carry out his responsibilities with the auditor's criteria must have a minimum education level of Starata one (S1), have competence in auditing, accounting, government administration, communicates and already has an auditor functional position certificate and follows continuing professional education and training. Auditing standards require an auditor to use his professional skills carefully and thoroughly, have the expertise and educational background of formal auditing and sufficient work experience in the profession.

Work experience is the level of mastery of knowledge and skills possessed by employees in work that can be measured from the period of work 1 and the type of work that the employee has done in a certain period. This is in line with the theory stated by Robbins and Timothy (2008) that work experience is based on employees' knowledge and skills. Martoyo (2007) and Alwi (2001) state that work experience is based on the length of work or the length of time an employee has worked. Syukur (2001) and Hariandja (2002) state that work experience is based on the type of work that has been done during a certain period.

Innovative behavior can improve employee performance, the influence will be stronger when employees have high work experience. Patterson (2014) innovative behavior is the process by which individuals are able to work with strong 
innovation power. By communicating one's intellectual capital to others. Innovative behavior can be interpreted as the degree to which a person actually conducts innovation behavior, it can also be understood as a behavior where someone voluntarily provides access to others about innovation and experience.

Lukito et.al (2016) found work experience to influence performance. In line with previous research conducted by Poh and $\mathrm{Zi}$ (2001), Michael et.al (2011), and Labre nz (2014) which states that work experience can improve performance. Kotter and Heskett (1992) state culture in organizations can have a significant impact on long-term economic performance. Organizations with a culture that emphasizes every major component of managerial and managerial leadership at all levels performing mel ebihi organizations that do not have these characteristics with a big difference.

A strong culture helps business performance because it creates an extraordinary level of motivation in employees. Values and behaviors shared together make people feel comfortable working for an organization. Robbins and Judge (2011) state that culture is a system that is owned by members of the organization that makes the organization different from other organizations. Kwan JG and Eddy MS (2013) found that culture influences performance. This result is in line with CM Sibuea Agnesi and Anthon Rustono (2015), Tri Mardiana and Sucahyo Heriningsih (2016). In addition Nur Chasanah (2008) states culture is very important to empower staff or employees, an increasing strength is the need to instill in each and every person is very necessary for those who understand the true meaning of culture.

Mangkunegara (2000) states that performance is the result of work achieved by someone in carrying out tasks in accordance with the responsibilities given to him. Factors affecting performance is the ability (ability) and motivation factors. Wood and Bailey, (2001) conducted research and the results support the theory of goal setting Goal Setting Theory).
Lukito et.al (2016) found that motivation has a positive effect on employee performance. This means that when motivation is increased, employee performance increases. This supports previous research by Galia (2007), Cheng (2011), Patterson (2014) which states that intrinsic motivation can improve performance. Based on some of the research above explains that the higher the motivation of individuals will have an impact on performance this is in line with Hezerbeg's motivation theory (1987). Kwan JG and Eddy MS (2013) suggested that culture and self-efficacy influence employee performance, as well as cultural influence on employee performance through self-efficacy as an intervening variable. The results of this study explain the motivation theory and goal setting theory where individuals with good culture selfefficacy will make individual motivation increase and lead to performance due to the target to be achieved (Goal Setting Theory).

Bandura (2000) suggested that the importance of self-efficacy will affect the effort required and ultimately seen from performance. In addition, research conducted by Nur Chasanah (2008) found that self-efficacy influences performance.

This study is a replication of research from Mardiana and Sucahyo (2016), where there are differences and renewal with this study, namely the addition of work experience variables.

Based on the description on the background of the problem, the problem formulation in this study is as follows:

1. Does work experience affect the Auditor's performance?

2. Does motivation affect the Auditor's performance?

3. Does culture influence Auditor performance?

4. Does work experience, motivation, culture influence performance?

\section{Research Methodology}

This research is an explanatory research explaining the relationship between 
variables through hypothesis testing conducted at the Maros Regency Inspectorate and Makassar City Inspectorate. Data obtained using the survey instrument method used in the form of a questionnaire. The research sample of 60 respondents who in the sample using a purposive sampling method. Data were analyzed using multiple regression methods.

Sources of data in this study are primary data and secondary data. Primary data in this study were obtained directly from individual respondents, namely internal auditors at the Makassar City and Maros Regency Inspectorates. While the secondary data in this study in the form of information obtained through supporting documents regarding the object under study.

Hypothesis testing is done by multiple regression analysis methods (multiple regression analysis) which is used to determine the effect of the dependent variable with several independent variables. This test is used to determine the effect of work experience variables (WE), motivation (MV), culture (CL) on auditor performance (K) mediated by Self Efficasy (SE). The linear regression equation is as follows:

Table 1. Questionnaire

\begin{tabular}{clcc}
\hline No & \multicolumn{1}{c}{ Information } & amount & $\%$ \\
\hline 1 & Total questionnaires distributed & 80 & $100 \%$ \\
2 & $\begin{array}{l}\text { Questionnaire that is incomplete data or } \\
\text { filling }\end{array}$ & 15 & $19 \%$ \\
3 & $\begin{array}{l}\text { Questionnaire that is not filled out or not } \\
\text { returned }\end{array}$ & 5 & $6 \%$ \\
4 & Total processed questionnaire & 60 & $75 \%$ \\
\hline
\end{tabular}

Source: Data Processed, 2018

The Internal Auditor gender with the male sex is 37 people $(62 \%)$, and women are 23 people $(38 \%)$. This shows that the auditor is dominated by men, this condition can be a consideration that if it is open, the addition of new auditors should prioritize and prioritize the gender of women with the condition that they must meet the specified qualifications.

Age
$Y=\beta o+\beta 1 X 1+\beta 2 X 2+\beta 3 X 3+\beta 4 X 4+$

e

Description:

$\mathrm{Y}=$ APIP performance

$\beta 0=$ constant

$\beta 1, \beta 2, \beta 3, \beta 4=$ Constants

$\mathrm{X} 1=$ work experience

$\mathrm{X} 2$ = Motivation

$\mathrm{X} 3$ = Organizational Culture

$\mathrm{X} 4=$ Self Efficacy

$\mathrm{e}=$ error

\section{Results and Discussion}

The populations in this study were internal auditors in Maros Regency and Makassar City. The samples in this study are civil servants (PNS) who work in the scope of the Regional Government of Maros Regency and Makassar City. Researchers submit questionnaires and take back the questionnaire. The questionnaires distributed totaled 80, with details of 40 copies for Maros Regency internal auditors and 40 copies of Makassar City internal auditors. 
working hours in carrying out audits must be given more opportunities so that the experience and problems in carrying out work as an auditor is getting better.

\section{Last education}

The level of education of the Internal Auditor in this study consisted of strata 1 (S1) totaling 34 people (56\%). Whereas Internal Auditors with postgraduate education (S2) numbered 26 people (44\%). Table 5.2 indicates that the level of knowledge and ability of Internal Auditors with an S1 degree is more dominant so that in carrying out professional and responsive supervision and examinations to encourage the realization of good financial governance.

\section{Years of service}

Internal auditors who have work experience between 0 - 5 years totaling 12 people (20\%), Internal Auditors who have work experience of between 6-10 years totaling 25 people $(42 \%)$. Furthermore, the work experience of Internal Auditors between 11-15 years totals 15 people (25\%) and Internal Auditors who have work experience of more than 16 years totaling 8 people $(13 \%)$. It shows that work experience between 6 years and 10 years, $42 \%$ of which are owned by Internal Auditors have enough experience in conducting audits and supervision in regional financial management. A summary explanation of the description above can be seen in table 5.2 following.

Table 2. Gender, Age, Education, and Years of Research Respondents

\begin{tabular}{|c|c|c|c|c|}
\hline No. & Characteristics & Criteria & $\begin{array}{l}\text { Frequency } \\
\text { (person) }\end{array}$ & $\begin{array}{c}\text { Percentage } \\
(\%)\end{array}$ \\
\hline \multirow[t]{3}{*}{1} & Gender & Male & 37 & 62 \\
\hline & & Girl & 23 & 38 \\
\hline & & Total & 60 & 100 \\
\hline \multirow[t]{5}{*}{2} & Age & 20 to 30 years & 6 & 10 \\
\hline & & 31 to 40 years & 29 & 48 \\
\hline & & 41 to 50 years & 17 & 28 \\
\hline & & $\begin{array}{l}\text { More than } 50 \\
\text { years }\end{array}$ & 8 & 14 \\
\hline & & Total & 60 & 100 \\
\hline \multirow[t]{4}{*}{3} & Education & Bachelor degree) & 34 & 56 \\
\hline & & Masters (S2) & 26 & 44 \\
\hline & & Doctorate (S3) & - & - \\
\hline & & Total & 60 & 100 \\
\hline \multirow[t]{5}{*}{4} & Years of service & 0 to 5 years & 12 & 20 \\
\hline & & 6 to 10 years & 25 & 42 \\
\hline & & 11 to 15 years & 15 & 25 \\
\hline & & $\begin{array}{l}\text { More than } 16 \\
\text { years }\end{array}$ & 8 & 13 \\
\hline & & Total & 60 & 100 \\
\hline
\end{tabular}

Source: Data Processed, 2018

Descriptive statistics of this research variable are seen from the minimum (Min), maximum (Max) and average (Mean) values. The sample data used in this study were 60 respondents. Based on the data collected, the results of the respondents' answers are shown in table 3 below. 
Table 3. Descriptive Statistics

\begin{tabular}{lccccc}
\hline \multicolumn{1}{c}{ Variable } & \multicolumn{2}{c}{ Theoretical } & \multicolumn{3}{c}{ The Real Range } \\
& Rin & Max & Min & Max & \\
& 7 & 35 & 15 & 35 & 22.43 \\
\hline WE (Work & & & & & \\
Experience) & 8 & 40 & 10 & 32 & 20.95 \\
Motivation (MV) & 6 & 30 & 6 & 28 & 12.60 \\
Culture (CL) & 7 & 35 & 7 & 30 & 14.50 \\
Self Efficacy (SE) & 6 & 30 & 18 & 30 & 32.10 \\
Auditor & & & & & \\
Performance (K) & & &
\end{tabular}

Source: Data Processed, 2018

Work experience is according to Foster (2001) there are several indicators to determine an employee's work experience, namely: the length of time or work period, which means a measure of the length of time or years of work a person has taken, better in understanding the tasks to be done and work well done. And work experience (WE) has 3 indicators: (1.) Length of time or work period, (2.) Level of knowledge and skills possessed, (3.) Mastery of work.

Work motivation is a psychological force in a person that determines the direction of one's behavior in the organization, the level of effort, and persistence in the face of obstacles. And Motivation has 2 indicators: (1.) Insterensic, (2.) Esterensic.

Culture is a system or patterns of values, symbols, rituals, myths, and practices that continue; directing people to behave quickly in an effort to solve the problem Robbins and Judge (2008). Culture has 3 indicators, namely: (1.) Innovation and courage to make decisions, (2.) Team orientation, (3.) Aggressiveness.

Self-efficacy is a person's self-confidence to carry out tasks at a certain level that affects personal activity towards the achievement of Jones's (1986) task. Self Efficacy has 4 indicators, namely: (1.) Feeling able to do work, (2.) Better ability, (3.) Happy with challenging work, (4.) Satisfaction with work.

Performance is the result of work achieved by a person in carrying out the tasks assigned to him based on skill, experience, resilience and time. Fisher and Richard T (2001) suggested that Performance has 4 indicators, namely: (1.) Quality of work, (2.) Quantity of work, (3.) Responsibility for work, (4.) Standards of Work results.

Testing the Validity and Reliability of Instruments

Validity and Reliability Tests of the instruments have been carried out and all data are valid and reliable. In determining the feasibility of an item to be used, a significance coefficient correlation test is usually performed at the 0.05 significance level, meaning that an item is considered valid if it has a significant correlation to the total score. The results of the calculation of each indicator have a significant value of all variables.

Reliability test is used to measure the consistency of statements from time to time. In this study the reliability test uses the Cronbach value. Alpha A variable is said to be reliable if it gives a Cronbach Alpha value> 0.60. All variables have Cronbach Alpha> 0.60 so that all of them are declared reliable.

Classic assumption test

Before the regression analysis can be interpreted, it is first tested classical assumptions which include the assumption of normality, heterokedastisitas, and multicollinearity.

Normality test 
Normality test uses histogram chart analysis and normal probability plot and One Sample Kolmogrof-Smirnov statistical analysis. The test results show that evenly distributed and clustered in the middle of this case means that the distribution data is normal.

\section{Multicollinearity Test}

Multicollinearity test to test whether the regression model found a correlation between independent variables. A good regression model where there should be no correlation between independent variables. Multicollinearity test uses VIF value and tolerance value. The existence of multicollinearity indicated tolerance value $<0.1$, and VIF value> 10. The results of the calculation of tolerance and VIF values showed a tolerance value greater than 0.1 , and a VIF value less than 10 indicates that this regression model had no multicollinearity problem.
Heterokedasticity Test

Heteroscedasticity testing uses a plot graph between the predicted value of the dependent variable (dependent) internal audit performance, namely ZPRED with the residual SRESID. The results showed that there were no clear patterns and points spread above and below the number 0 on the $y$ axis and concluded heteroscedasticity did not occur.

\section{Hypothesis test}

\section{Effect of Work Experience on Auditor Performance}

Table 7 regression analysis using the SPSS program produces a summary model showing that the magnitude of adjusted $\mathrm{R}^{2}$ is 0.525 , this means that $52.5 \%$ of the variation in Auditor Performance can be explained by variations of the independent variables of work experience, while $47.5 \%$ is explained by other causes outside model.

Table 7. Summary Model

\begin{tabular}{ccccc}
\hline Model & R & R Square & $\begin{array}{c}\text { Adjusted R. } \\
\text { Square }\end{array}$ & $\begin{array}{c}\text { Std. Error of the } \\
\text { Estimate }\end{array}$ \\
\hline 1 & $.730^{\mathrm{a}}$ & .533 & .525 & 2,188 \\
\hline
\end{tabular}

a. Predictors: (Constant), WE

Source: Data Processed, 2018

Table8 the results where the constants of 11.113 and a regression coefficient of experience working the 0447 audit performance variables influenced by the work experience with the mathematical equation: Performance $=11.113$ +0447 Auditor Work Experience.

Table 8. Coefficients

\begin{tabular}{lcccc}
\hline Model & $\begin{array}{c}\text { Unstandardized } \\
\text { Coefficients } \\
\text { B Std. Error }\end{array}$ & $\begin{array}{c}\text { Standardized } \\
\text { Coefficients } \\
\text { Beta }\end{array}$ & $\mathrm{t}$ & Sig. \\
\hline (Constant) & $11,1131,420$ & & 7,828 & .000 \\
WE & .447 .055 & .730 & 8,137 & .000 \\
\hline
\end{tabular}

a. Dependent Variable: $\mathrm{K}$

Source: Data Processed, 2018

Based on table 7 and table 8 where the results show that audit performance is influenced by work experience.

\section{Effect of}

Motivationon Auditor Performance 
Table 9 regression analysis of the summary model shows that the magnitude of adjusted $\mathrm{R}^{2}$ is 0.326 , this means that $32.6 \%$ of the variation in Auditor Performance can be explained by variations of the independent motivational variables, while $67.4 \%$ is explained by other causes outside the model.

Table 9. Summary Model

\begin{tabular}{ccccc}
\hline Model & R & R Square & $\begin{array}{c}\text { Adjusted R. } \\
\text { Square }\end{array}$ & $\begin{array}{c}\text { Std. Error of the } \\
\text { Estimate }\end{array}$ \\
\hline 1 & $.581^{\text {a }}$ & 338 & .326 & 2,606 \\
\hline
\end{tabular}

a. Predictors: (Constant), MV

Source: Data Processed, 2018

Table 10 results where the constant is 15.529 and the regression coefficient of motivation is 0.330 , the auditor performance variable is influenced by motivation with mathematical equations: Auditor Performance $=15,529+$ 03,330 Motivation

Table 10. Coefficients

\begin{tabular}{|c|c|c|c|c|}
\hline Model & $\begin{array}{c}\text { Unstandardized } \\
\text { Coefficients } \\
\text { B Std. Error }\end{array}$ & $\begin{array}{c}\text { Standardized } \\
\text { Coefficients } \\
\text { Beta }\end{array}$ & $\mathrm{t}$ & Sig. \\
\hline$\overline{(\text { Constant) }}{ }^{1}$ & $15,5291,314$ & & 11,822 & .000 \\
\hline MV & .330 .061 & .581 & 5,437 & .000 \\
\hline
\end{tabular}

a. Dependent Variable: K

Source: Data Processed, 2018

Based on table 9 and table 10 where the results indicate that the auditor's performance is influenced by motivation.

\section{Cultural Influences on Auditor performance}

Table 11 of the model summary regression analysis shows that the magnitude of adjusted $\mathrm{R}^{2}$ is 0.228 , this means that $22.8 \%$ of Auditor Performance variation can be explained by variations of cultural independent variables, while $77.2 \%$ is explained by other causes outside the model.

Table 11. Summary Model

\begin{tabular}{ccccc}
\hline Model & R & R Square & $\begin{array}{c}\text { Adjusted R. } \\
\text { Square }\end{array}$ & $\begin{array}{c}\text { Std. Error of the } \\
\text { Estimate }\end{array}$ \\
\hline 1 & $.491^{\mathrm{a}}$ & .241 & .228 & 2,790 \\
\hline
\end{tabular}

a. Predictors: (Constant), CL

Source: Data Processed, 2018

Table 12 results where the constant is 19.046 and the culture regression coefficient is 0.269 , the audit performance variable is influenced by culture with a mathematical equation: Auditor's Performance $=19,046+0,269$ Culture. 
Table 12. Coefficients

\begin{tabular}{lccccc}
\hline Model & $\begin{array}{c}\text { Unstandardized } \\
\text { Coefficients } \\
\text { B Std. Error }\end{array}$ & $\begin{array}{c}\text { Standardized } \\
\text { Coefficients } \\
\text { Beta }\end{array}$ & $\mathrm{t}$ & Sig. \\
\hline (Constant) & $19,046,867$ & & 21,959 & .000 \\
CL & 269.063 & .491 & 4,292 & .000 \\
\hline
\end{tabular}

Source: Data Processed, 2018

Based on table 11 and table 12 where the results indicate that auditor performance is influenced by culture.

Effect of Work Experience, Motivation, Culture on Auditor Performance mediated by Self-efficacy
Table 5.13 summary regression models showed that the adjusted $\mathrm{R}^{2}$ is 0.697 this means that $69.7 \%$ of the variation Self-efficacy can be explained by the variation of the independent variables work experience, motivation and culture, while $30.3 \%$ is explained by other causes outer model.

Table 13. Summary Model

\begin{tabular}{ccccc}
\hline Model & R & R Square & $\begin{array}{c}\text { Adjusted R. Std. Error of the } \\
\text { Square }\end{array}$ & Estimate \\
\hline 1 & $.844^{\mathrm{a}}$ & .713 & .697 & 3,071 \\
\hline
\end{tabular}

a. Predictors: (Constant), CL, WE, MV

Source: Data Processed, 2018

The results in table 14 which provide unstandardized beta values for work experience variables are 0.406 , motivation variables are 0.243 and cultural variables are
0.817 and significant are, among others, work experience variables (0.001), motivation (0.038) and culture (0.000).

Table 14. Coefficients

\begin{tabular}{lcccc}
\hline Model & $\begin{array}{c}\text { Unstandardized } \\
\text { Coefficients } \\
\text { B Std. Error }\end{array}$ & $\begin{array}{c}\text { Standardized } \\
\text { Coefficients } \\
\text { Beta }\end{array}$ & $\mathrm{t}$ & Sig. \\
\hline (Constant) ${ }^{1}$ & $9,4062,205$ & & 4,266 & .000 \\
WE & .406 .121 & .378 & 3,348 & .001 \\
MV & .243 .115 & .244 & 2,122 & .038 \\
CL & $.817,072$ & .849 & 11,370 & .000 \\
\hline
\end{tabular}

Source: Data Processed, 2018

Whereas in table 15 regression analysis where the influence of work experience, motivation, culture and self-efficacy shows that the amount of adjusted R2 of 0.850 this means that $85 \%$ variation in Auditor Performance can be explained by variations of the independent variables work experience, motivation, culture and self-efficacy while $15 \%$ is explained by other reasons outside the model. 
Table 15. Summary Model

\begin{tabular}{ccccc}
\hline Model & R & R Square & $\begin{array}{c}\text { Adjusted R. Std. Error of the } \\
\text { Square }\end{array}$ & \begin{tabular}{c} 
Estimate \\
\hline 1
\end{tabular} \\
\hline
\end{tabular}

a. Predictors: (Constant), SE, CL, WE, MV

Source: Data Processed, 2018

The results in table 16 which provide unstandardized beta values for work experience variables are 0.395 , motivation variables are 0.122 , cultural variables are 0.137 , and self- efficacy variables are 0.207 and significant are, among others, work experience variables $(0,000)$, motivation (0.014) , culture (0.012), and selfefficacy $(0,000)$

Table 16. Coefficients

\begin{tabular}{lccccc}
\hline Model & $\begin{array}{c}\text { Unstandardized } \\
\text { Coefficients } \\
\text { B Std. Error }\end{array}$ & $\begin{array}{c}\text { Standardized } \\
\text { Coefficients } \\
\text { Beta }\end{array}$ & $\mathrm{t}$ & Sig. \\
\hline (Constant) & $5,1401,017$ & & 5,055 & .000 \\
WE & .395 .053 & 646 & 7,426 & .000 \\
MV & .122 .048 & .214 & 2,547 & .014 \\
CL & $.137,052$ & .250 & 2,611 & .012 \\
SE & .207 .054 & .364 & 3,868 & .000 \\
\hline
\end{tabular}

a. Dependent Variable: $\mathrm{K}$

Source: Data Processed, 2018

Baron and Kenny (1986) state that for the mediation test it is necessary to estimate three regression tests, namely (1) the regression test of the independent variable to the mediator, (2) independent of the dependent, and (3) the mediator of the dependent.

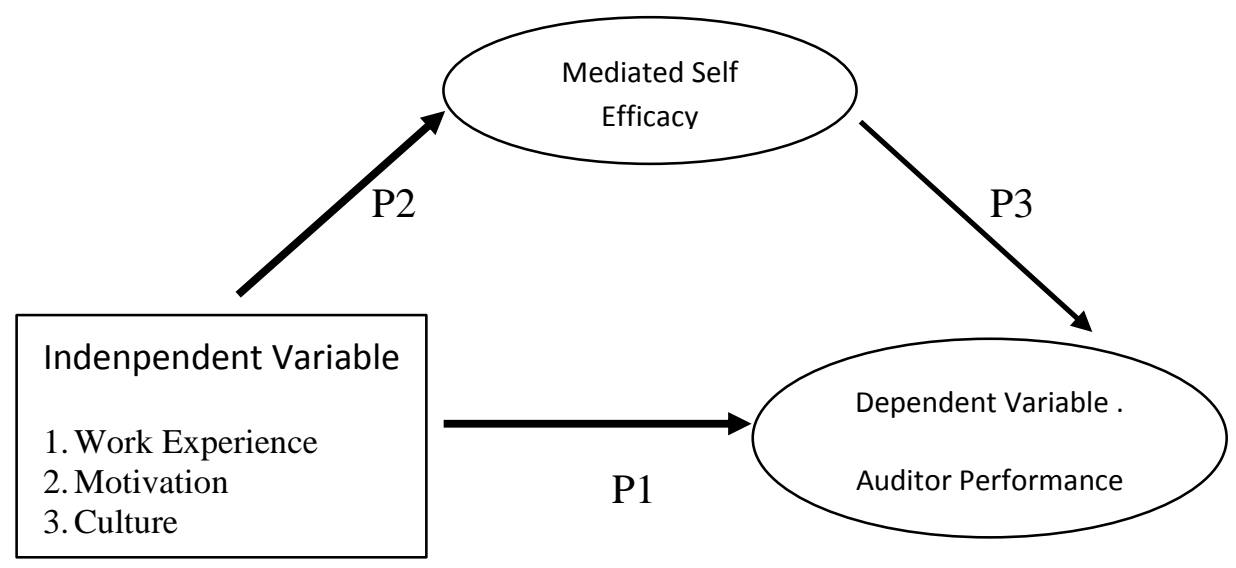

Fig 3. Mediation

\section{Direct Influence}

To calculate the direct effect, the following formula is used:

a. Equation 1
1. Effect of work experience on selfefficacy $=0.406$

2. Effect of motivation on self-efficacy $=$ 0.243 
3. Cultural influences on self efficacy = 0.817

\section{b. Equation 2}

1. Effect of work experience on auditor performance $=0.395$

2. The influence of motivation on auditor performance $=0.122$

3. Cultural influences on auditor performance $=0.137$

4. The effect of self efficacy on auditor performance $=0.207$

The path analysis results show that work experience, motivation and culture directly influence the auditor's performance and also indirectly influence self-efficacy (as an intervening) then to the auditor's performance.

Indirect Effect (p2 x p3)

a. Effect of work experience on auditor performance mediated by self efficacy $=(0.406$ $\mathrm{x} 0.207)=0.084$

b. The influence of motivation on auditor performance is mediated by self efficacy $=$ $(0.243 \times 0.207)=0.050$

c. Cultural influences on auditor performance mediated by self efficacy $=(0.817 \times 0.207)=$ 0.169

Total direct effect $(\mathrm{p} 1+(\mathrm{p} 2 \times \mathrm{p} 3)$

a. Effect of work experience on auditor performance mediated by self efficacy $=0.395$ $+0.084=0.479$.

b. The influence of motivation on auditor performance is mediated by self efficacy $=$ $0.122+0.050=0.172$

c. Cultural influences on auditor performance mediated by self efficacy $=0.137+0.169=$ 0.306

Based on calculations using Baron and Kenny the total direct effect of work experience on auditor performance mediated by self-efficacy is 0.479 compared to the indirect effect of work experience on auditor performance mediated by self-efficacy of 0.084 . While total direct effect of motivation on the performance of auditors mediated by self-efficacy of 0172 compared to the indirect influence of motivation on the performance of auditors mediated by selfefficacy by 0050 , and total direct influence of culture on the performance of auditors mediated by self-efficacy se great 0306 and compared with the indirect effect of culture on auditor performance mediated by self-efficacy by 0.169 Seeing the results of the total direct relationship of all variables and compared with the indirect effect is interpreted that the self-efficacy variable is a mediating variable that strengthens the relationship of work experience, motivation and culture towards auditor performance.

Calculate the standard error of the indirect effect coefficient using the sobel test as follows

a. Effect of work experience on the performance of the auditor's selfefficacy as a mediator

$\mathrm{Sp} 2 \mathrm{p} 3=\sqrt{\mathrm{p}^{2} \mathrm{Sp} 2^{2}+\mathrm{p} 2 \mathrm{Sp} 3^{2}+\mathrm{Sp} 2^{2} \mathrm{Sp} 3^{2}}$ Sp2p3 $=\sqrt{(0.207)^{2}(0.121)^{2}+(0.406)^{2}(0.054)^{2}}$
$+(0.121)^{2}(0.054)^{2}$

Sp2p3 $=\sqrt{(0.043)(0.015)+(0.165)(0.003)+}$ (0.015) (0.003)

$\mathrm{Sp} 2 \mathrm{p} 3=\sqrt{0.001+0,000+0,000}$

$\mathrm{Sp} 2 \mathrm{p} 3=\sqrt{0.001}$

Sp2p3 $=0.032$

Based on the results of $\mathrm{Sp} 2 \mathrm{p} 3$ then calculate the $t$ value of the mediating effect using the following formula:.

$$
\begin{aligned}
& \mathrm{t}=\mathrm{p} 2 \mathrm{p} 3 / \mathrm{sp} 2 \mathrm{p} 3 \\
& \mathrm{t}=0.084 / 0.032 \\
& \mathrm{t}=2,625
\end{aligned}
$$


Based on the results of the calculated t value 2.625 is greater than $\mathrm{t}$ table with a significance level of 0.05 that is equal to 0.250 it can be concluded that the mediation coefficient is 0.084 significant which means there is a mediating effect.

\section{b. The influence of motivation on the performance of the auditor's self- efficacy as mediation}

$\mathrm{Sp} 2 \mathrm{p} 3=\sqrt{\mathrm{p}^{2} \mathrm{Sp}^{2}+\mathrm{p} 2 \mathrm{Sp}^{2}+\mathrm{Sp}^{2}}$ $\mathrm{Sp} 3^{2}$

$\mathrm{Sp} 2 \mathrm{p} 3=\sqrt{(0.207)^{2}(0.115)^{2}+(0.243)^{2}(0.054)^{2}}$ $+(0.115)^{2}(0.054)^{2}$

$\mathrm{Sp} 2 \mathrm{p} 3=\sqrt{(0.043)(0.013)+(0.059)(0.003)+}$ (0.013) (0.003)

$\mathrm{Sp} 2 \mathrm{p} 3=\sqrt{0.001+0,000+0,000}$

$\mathrm{Sp} 2 \mathrm{p} 3=\sqrt{0.001}$

$\mathrm{Sp} 2 \mathrm{p} 3=0.032$

Based on the results of $\mathrm{Sp} 2 \mathrm{p} 3$ then calculate the $t$ value of the mediating effect using the following formula:

$$
\begin{aligned}
& \mathrm{t}=\mathrm{p} 2 \mathrm{p} 3 / \mathrm{sp} 2 \mathrm{p} 3 \\
& \mathrm{t}=0.050 / 0.032
\end{aligned}
$$

$$
t=1,563
$$

Based on the results of the $t$ value of 1.563 is greater than $t$ table with a significance level of 0.05 that is equal to 0.250 it can be concluded that the mediation coefficient is 0.050 significant which means there is a mediating effect.

\section{c. Cultural influences on auditor performance self-efficacy as mediation}

$\mathrm{Sp} 2 \mathrm{p} 3=\sqrt{\mathrm{p} 3^{2} \mathrm{Sp} 2^{2}+\mathrm{p} 2 \mathrm{Sp} 3^{2}+\mathrm{Sp}^{2} \mathrm{Sp} 3^{2}}$

Sp2p3 $=\sqrt{(0.207)^{2}(0.072)^{2}+(0.817)^{2}(0.054)^{2}}$ $+(0.072)^{2}(0.054)^{2}$
$\mathrm{Sp} 2 \mathrm{p} 3=\sqrt{(0.043)(0.005)+(0.667)(0.003)+}$ (0.005) (0.003)

$\mathrm{Sp} 2 \mathrm{p} 3=\sqrt{0,000+0.002+0,000}$

$\mathrm{Sp} 2 \mathrm{p} 3=\sqrt{0.002}$

Sp2p3 $=0.045$

Based on the results of $\mathrm{Sp} 2 \mathrm{p} 3$ then calculate the $t$ value of the mediating effect using the following formula:

$$
\begin{aligned}
& \mathrm{t}=\mathrm{p} 2 \mathrm{p} 3 / \mathrm{sp} 2 \mathrm{p} 3 \\
& \mathrm{t}=0.169 / 0.045
\end{aligned}
$$

$$
\mathrm{t}=3,756
$$

Based on the results of the $t$ value of 3.756 is greater than $t$ table with a significance level of 0.05 that is equal to 0.250 , it can be concluded that the mediation coefficient is 0.169 , which means that there is a mediating effect.

\section{Effect of Work Experience on Auditor Performance}

Testing the work experience and performance of auditors with a significant level of 0,000 and a regression coefficient of 0.447 which shows a positive relationship. This means that the higher the work experience of an auditor, the performance of an auditor is increasing. Based on these results the work experience hypothesis affects the auditor's performance received.

Based on the results of the characteristics of respondents long time working in table 5.2 explains that respondents long worked from 5 years to 15 years by $67 \%$. The results of this study indicate that the longer an auditor works, the better in understanding his duties and functions so that an auditor easily increases audit performance. With the increase in audit performance in line with the goal-setting theory (Goal Setting Theory) which provides an explanation of the behavior that determines a person to be able to decide what should be done to 
achieve the objectives to be achieved, in this case the objectives of an auditor how to improve performance when conducting audits.

This study is in line with research by Komang EY et.al (2016) finding that work experience influences performance. In addition, the study is in line with research by Poh and $\mathrm{Zi}$ (2001), Michael et.al (2011), and Labrenz (2014) showing work experience influences performance, where work experience is improved, so performance increases.

\section{Effect of Motivation on Auditor Performance}

The results of this study where motivation affects the performance of auditors with a significant level of 0,000 with a regression coefficient of 0.330 and shows a positive relationship. This shows that the higher the motivation of an auditor, the more performance increases. Based on the results of this study, the hypothesis of the influence of motivation on auditor performance was accepted. Based on table 5.2 the characteristics of respondents where the age between 20 years to 50 years by $58 \%$ and the sex of the respondents $62 \%$ of men is interpreted that the age of the respondent in the productive period so that it can be said that the respondents' motivation level is very high. With a very high motivation will encourage productivity that impact on performance in conducting examinations.

The results of this study are in line with Herzberg and Frederick (in Gibson stating that intrinsic motivation is a driving force that arises from within an employee to work well in order to achieve higher performance. In addition, Nawawi's (2001) study states that extrinsic motivation is a work driver sourced from outside the worker himself as an individual in the form of a condition that requires him to carry out the work to the fullest.

In addition this study is in line with research by Heri Puspito et.al (2016), Galia (2007), Cheng (2011), Patterson (2014) states that intrinsic and extrinsic motivation affect performance, which means that when intrinsic and extrinsic motivation is increased, then employee performance increases. This study is also in line with the research of Darolia et.al (2010, Agustina et.al (2013), Murti (2013), Hayati (2012), and Juliani (2007) who suggested that intrinsic and extrinsic motivation influence performance.

This study explains the theory of motivation Herzberg and Frederick cited by Luthans (1992), which is classified as a motivational factor between

is achievement (success), recognition (recognition or awards), work itself (the work itself), responsibility (responsibility) and advancement (development). In addition, it explains the Goal Setting Theory (Goal Setting Theory) theory which states that individual behavior is governed by one's ideas (thoughts) and intentions, goals can be seen as goals or levels of performance to be achieved by individuals.

\section{Cultural Influences on Auditor Performance}

Cultural testing results affect the performance of auditors where a significant level of 0,000 and a regression coefficient of 0.269 results interpreted as hypotheses the influence of culture on auditor performance is accepted.

Based on table 5.2 regarding respondents $76 \%$ of respondents aged 31 years to 50 years meant that all respondents were adults in terms of thinking and acting so that this triggers a good culture. In addition, the education level of the respondents was $44 \%$ post graduate and interpreted in the knowledge of the respondents was very adequate so that the culture and performance of respondents was high. This is in line with Sugiwardani (2012) state culture (culture) can be defined as a set of values, beliefs, understandings, and norms underlying principal individuals in an organization. Meanwhile, according to Hofstede (1994) culture can be interpreted as values that are reflected in behavior in an organization.

This research is in line with Kotter and Hesket's (1992) research finding that culture can have a significant impact on long-term economic 
performance and organization will be an even more important factor in determining organizational success. Whereas research by Sutanto (2002) suggests that a strong culture will trigger employees or staff to think, behave and behave in accordance with organizational values. Suitability between culture and employees or staff in the organization will lead to motivation and effort and improve performance. In addition, the results of Mardiana and Sucahyo's research (2016), Chasanah (2008), which states that the more an employee runs a culture well, the easier it is for employees to achieve work goals as an assessment of their performance.

\section{The Effect of Work Experience, Motivation, and Culture on Auditor Performance is mediated by Self-efficacy}

The results of this study are based on calculations using Baron and Kenny the total direct effect of work experience on auditor performance mediated by self-efficacy is 0.479 compared to the indirect effect of work experience on auditor performance mediated by selfefficacy of 0.084 . While the total direct effect of motivation on auditor performance is mediated by self-efficacy by 0.172 compared to the indirect effect of motivation on auditor performance mediated by self-efficacy by 0.050 , and the total direct cultural influence on auditor performance is mediated by self-efficacy by 0.306 and compared with the indirect effect of culture on auditor performance mediated by self-efficacy is 0.169 .

Seeing the results of the total direct relationship of all variables and compared with the indirect effect is interpreted that the selfefficacy variable is a mediating variable that strengthens the relationship of work experience, motivation and culture to the auditor's performance and the hypothesized work experience, motivation, and culture influence the Auditor's Performance mediated by Selfefficacy received. This study is in line with the research of Mardiana et.al (2016) who found that the influence of motivation and culture influences performance in mediation by self-efficacy, in addition Chasanah (2008) research found that motivation and work experience affect performance.

\section{Conclusion}

Based on the results of the research and discussion of the research, it was concluded that the auditor's work experience in the Inspectorate of Maros Regency and Makassar City based on the results of the study showed the majority of respondents tended to have very good work experience. Research shows that culture has a significant and positive influence on auditor performance.

\section{Implications}

The results of this study provide both theoretical and practical implications for the formulation of a policy policy in determining the performance of an auditor in carrying out, which is expected to provide additional benefits in the form of empirical research references regarding the effect of work experience, motivation and culture on auditor performance with self-efficacy as mediation. The results of this study are used as reference material for future research. As information material to the auditors in improving audit performance in carrying out the audit tasks and reviewing financial statements.

\section{Limitation}

This research was conducted without being separated from the existence of several limitations that can reduce the quality of research data. The limitation is that there are still other independent variables that can be included in addition to the variables that have been tested in this study. Respondents in the research need to be considered to be expanded so that research results can be generalized.

\section{Suggestion}

Based on the conclusions of this study, it is recommended for future research that is Future research to be considered to add several variables such as individual commitment variables as 
independent variables. Respondents in future research need to be considered to add several districts and cities so that this research can be generalized.

\section{References}

[1] Agnesi CM Sibuea and Anthon Rustono. 2015. The influence of organizational culture and self-efficacy on employee performance at PT. PLN (PERSERO) distribution of West Java and Banten. Bandung, ISSN: 2355-9357 eProceeding of Management: Vol.2, No.3 December 2015 | Page 2346.

[2] Alwi, Syarifuddin. 2001. Human Resource Management, Competitive Advantage Strategy, Faculty of Economics Publisher Agency, Yogyakarta.

[3] Bandura, A. 2000. Self-efficacy: The foundation of agency. In WJ Perrig \& A. Grob (Eds.), Control of human behavior, mental processes, and consciousness: Essays in honor of the 60th birthday of August Flammer (p. 17-33). Lawrence Erlbaum Associates Publishers.

[4] Baron, RM and Kenny, DA 1986. The Moderators-Mediators of Distinction Variables in Social Psychological Research: Conceptual, Strategic, and Statistical Considerations. Journal of Personality and Social Psychology, 51 (6), 1173-1182.

[5] . Chasanah, Nur. 2008. Analysts on the Effect of Empowerment, Self-Efficacy and Organizational Culture on Job Satisfaction in Improving Employee Performance (Empirical Study on Employees of PT. Mayora Tbk Regional Central Java and DIY). Thesis. Master of Management Study Program at Diponegoro University, Semarang.

[6] Cheng, P.-Y., Lin, M.-L., \& Su, C.K. 2011. Attitudes and motivations of students taking professional certificate examinations. Social Behavior and
Personality: An international journal , 39, 1303-1314.

[7] CR Darolia, Parveen Kumari, and Shashi Darolia. 2010. Perceived Organizational Support, Work Motivation, and Organizational Commitment as determinants of Job Performance: Journal of the Indian Academy of Applied Psychology Vol.36, No.1, 69-78.

[8] Fisher, Richard T. 2001. Role Stress, The Type A Behavior Pattern, and External Auditor Job Satisfaction and Performance. Journal of Behavior Research in Accounting 13: 143-171.

[9] Foster, B. 2001. Coaching for Improving Employee Performance. Jakarta: PPM.

[10] Gauls, Fabrice. 2007. An Invisible Frontier? Intrinsic-Extrinsic Motivations and Knowledge Sharing in Firms. France: CEREN Working Paper No. 16

[11] Gibson, James L., John M. Ivancevich, James H. Donnelly, Jr., and Robert Konopaske. 2003. "Organizations: Behavior, Structure, Process" (Eleventh Edition), Boston: McGraw-Hill Irwin.

[12] Gunawan, Kwan Jessica and Eddy Madiono Sutanto. 2013. THE INFLUENCE OF ORGANIZATIONAL CULTURE ON EMPLOYEE PERFORMANCE THROUGH SELF EFFICACY AND TEMPERAMENTS IN PT. NUTRIFOOD SURABAYA. Petra Christian University: AGORA Vol. 1, No. 1

[13] Hariandja, Marihot TE 2002. Human Resource Management. Jakarta: Grasido.

[14] Hayati, K. and Caniago, I. 2012. Islamic Word Ethic: The Role of Intrinsic Motivation, Job Satisfaction, Organizational Commitment, and Job Performance, SciVerse Science Direct.

[15] Herzberg, F. 1987. One More Time: How Do You Motivate Employees. Motivation: Harvard Business Review Paperback. Pages 3-14. 
[16] Hofstede, Geert. 1994. The Business of International Business is Culture. International Business Review Vol. 3, No. 1, pp. 1-14,1994.

[17] Juliani. 2007. Effect of Intrinsic Motivation on the Performance of Implementing Nurses in the Inpatient Installation of Dr. Pringadi Medan in 2007. Thesis of the University of North Sumatra.

[18] Jones, Gareth R. 1986. Socialization Tactics, Self-Efficacy, and Newcomers' Adjustments to Organizations. The Academy of Management Journal Vol. 29, No. 2 (Jun., 1986), pp. 262-279.

[19] Komang, EY, Nyoman, N. \& Wayan, B. 2016. Effect of Work Experience and Employee Placement on Employee Performance. E-journal Bisma Ganesha Educating University.

[20] Kotter, JP, and JL Heskett. 1992. Corporate Culture and Performance. New York: The Free Press.

[21] Labrenz, Soren. 2014. "The influence of HR Practices on Innovative behavior and the moderating effect of line manager behavior," University of Twente, vol. 7, 143.

[22] Lukito, Heri Puspito., Haryono, Andi Tri., Warso, and M Mukeri. 2016. Effect of Instructional Motivation, Extrinsic Motivation and Work Experience on Employee Performance (Study on Btpn Syariah Semarang). Journal of Management, 2 (2): 1-15.

[23] Luthans, Fred. 1992. Organizational Behavior 6th Editon. New York: McGrawHill, Inc.,

[24] Mangkumanegara, AP 2000. Corporate Human Resource Management. Bandung: Teen Rosdakarya.

[25] Mardiana, Tri and Sucahyo Heriningsih. 2016. Self Esteem Ability Mediates the Effect of Organizational Motivation and Culture on Performance. Proceedings International
Conference on Economics, Business and Social Sciences: Page 114. University of Islam Malang.

[26] Martoyo, Susilo. 2007, Human Resource Management, BPFE Yogyakarta.

[27] Michael, LA Hsu; Sheng Tsung Hou; and Hsueh Liang Fan. 2011. "Creative selfefficacy and innovative behavior in a service setting: optimism as a moderator," Journal of Creative Behavior, vol. 1, 104154.

[28] Murti, Harry et al. 2013. The Effect of Motivation on Employee Performance with Job Satisfaction Mediation Variables in PDAM Kota Madiun, Journal of Management and Accounting Research, Vol. 1, No. 1, February 2013.

[29] Nawawi. 2011. Human Resource Management: For Competitive Business, Gajahmada University Press, Yogyakarta.

[30] Patterson, Fiona; Mairre Kerrin; and Geraldine Gatto Roissard. 2014. "Characteristics and behavior of innovative people in organizations," Literature Review, vol 3, 1-53

[31] Poh, Zhang Ze; and Zi Juan, 2001, "Perceived organizational justice, job satisfaction, and leadership: How do they relate to each other," Journal of Basic and Applied Scientific Research.

[32] Rahmah, Agustina, Ahmad Alim Bachri and Anna Nur Faidah. 2013. THE INFLUENCE OF ORGANIZATIONAL COMMITMENT, INTRINSIC MOTIVATION AND EXTRINSIC MOTIVATION ON DOCTOR PERFORMANCE (Study of Physicians at Ulin District General Hospital Banjarmasin). Journal of Management Insights, Vol. 1, Number 3, October 2013.

[33] Robbins, Stephen P. and Timothy A. Judge. 2008. Organizational Behavior 12th Edition, Jakarta: Salemba Empat. 
[34] Robbins, Stephen P. and Timothy A. Judge. 2011. Organizational Behavior. 14th ed. England: Pearson.

[35] Sugiwardani, Resti. 2012. Analysis of the Influence of Budget Participation, Symmetrical Information, Culture and Organizational Commitment to Budgetary Slack. Business and Accounting Journal. Perbanas Economics Faculty, Surabaya.

[36] Sutanto, Aftono. 2002. The Role of Organizational Culture to Improve Job Satisfaction and Employee Performance. Journal of Economics and Business FE Ahmad Dahlan University Yogyakarta, Vol. 6., No.2, December.

[37] Gratitude. 2001. Research Methods and Presentation of Education Data. Semarang: Medya Wiyata.

[38] Wood. \& Bailey. 2001. Some Unanswered Questions About Goal Effects: A Recommended Change in Research Method. Australian Graduate School of Management. 